\title{
Brussels urged to back more basic science
}

Munich. A strong plea for basic research to be given a major role in the European Commission's next five-year Framework programme has come from the European Science and Technology Assembly (ESTA), a 100-member advisory committee set up two years ago with representatives from both industry and the academic community.

In a statement issued last week, ESTA acknowledges that the main role of the commission, which is preparing the first draft of the new Framework programme, to run from 1999 to 2003, is to support applications-oriented research. But it also says the commission should bear in mind industry's need to remain in touch with basic research.

In the past, fundamental research has been considered in Brussels as mainly the responsibility of individual countries. This has been changing in recent years; many research programmes in the current ECU12.3-billion (US\$15.2-billion) fourth
Framework programme, for example, include a basic research element, which tends to be heavily oversubscribed.

In addition, the current research training programme - Training and Mobility of Researchers - is widely used to promote the training of young basic scientists. But many European scientists now fear that the prevailing mood of budget cuts and targeted spending may erode even this small role in the next Framework programme.

In contrast, ESTA argues that support for both training young scientists and basic research should be expanded in the next Framework programme. The former, it says, is essential to provide industry with a highly skilled workforce already experienced in adapting to the international environment.

The assembly also argues that every programme in Framework V should include a basic research component. This would fund 'bottom-up' proposals, allowing researchers to help define how long-term industrial tar-

\section{German research spending stays low}

Munich. The funding of research in Germany over the past three years has not kept up with inflation, while the proportion of domestic research financed by industry has dropped significantly, according to statistics published last week.

In the introduction to a report analysing research and development (R\&D) spending, Jürgen Rüttgers, the German research minister, says that high wages, as well as a restrictive and bureaucratic research environment, have forced companies - particularly in the chemical
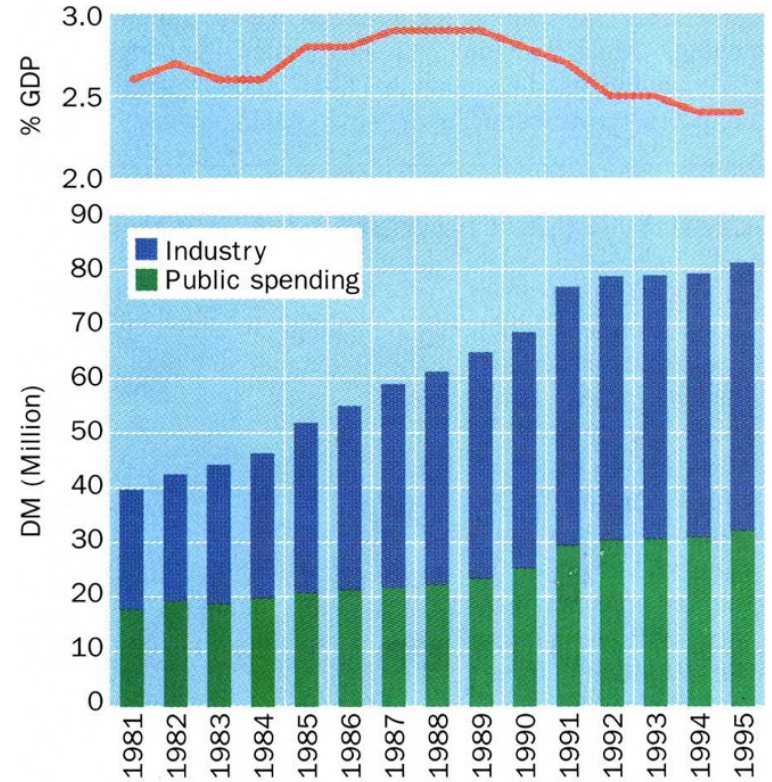

industry - to move

much of their R\&D activities abroad.

But his Social Democrat (SPD) opponents say that by focusing on industry, Rüttgers is trying to distract attention from the stagnation of public research funding in the past three years. Germany's federal research budget now stands at 2.3 per cent of gross domestic product (GDP), compared with 2.9 per cent in 1989. According to Reinhard Junker, an SPD spokesman on science, the effect is that the federal research budget is "at

least DM3 billion (US\$2 billion) short of what it should be".

The Bundesverband der Deutschen Industrie, German industry's umbrella group, has also reacted angrily to Rüttgers' attempts to blame industry for a slowdown in research budgets. "It is no use complaining about decreasing industrial research but still not taking effective measures to ease tax burdens and licensing procedures for R\&D departments," says a spokesman.

Quirin Schiermeier gets might be reached, and enhancing the benefits from serendipitous discoveries.

In its statement, ESTA says that the commission should develop 'common [scientific] objectives' between national research councils and Europe-wide research bodies, such as the European Southern Observatory, the European Molecular Biology Laboratory, in Heidelberg, and the European Laboratory for Particle Physics (CERN) in Geneva.

Indeed, some ESTA members would like the commission to recognize the expertise of large international laboratories in organizing major research programmes, and to give them responsibility for administering certain programmes.

Jan Borgman, the chairman of ESTA and formerly head of the Dutch National Research Council (NWO), is confident that the assembly's opinion will be taken seriously by the commission, in particular because it is shared by both its academic and industrial members. But whether its suggestions will be accepted will not be known until the first draft of the fifth Framework proposals is published at the end of the year.

Edith Cresson, the research commissioner, is said to be sympathetic to the plea that basic research should not be forgotten. But the Council of Ministers, made up of representatives of member states and facing pressing problems such as unemployment and agricultural policy, may need more convincing. Both the content and funding of the new Framework programme must be approved by both the council and the European Parliament.

ESTA is facing its own internal problems. Having argued unsuccessfully that ESTA needs more administrative help to handle its increasing burden of work - in the two years of its existence, the assembly has set up half a dozen working groups and plans still more - Borgman resigned at the end of March in protest at the workload he was having to carry.

ESTA's bureau, a group of 20 members, failed to agree on a successor last month. Borgman, who continues to hold the reins temporarily, says that he would stay in office if more help were to be provided from Brussels. But this seems unlikely, and a new chairman will probably be selected at the next ESTA assembly in July.

Meanwhile, biologist members of ESTA have agreed to set up an informal group, organized by François Gros, the former director of the Institut Pasteur in Paris, to suggest how the European Union should be targeting its biological research.

According to Gros, biology has become so complex that deciding on future priorities - taking account of the need for future industrial applications - needs wide consultation within industry and the academic community.

Alison Abbott 